\title{
PANEL ON BILLS OF SALE, CHATTEL MORTGAGES AND CONDITIONAL SALES AGREEMENTS
}

\author{
Members: W. F. Bowker, Chairman, Eldon Foote, J. M. Hope, and W. H. Hurlburt*
}

1. When a Bill of Sale or Conditional Sale Agreement must be completed and registered.

As some of the older cases put it, possession of goods after a secret sale or mortgage is a badge of fraud. The Bills of Sale Acr ${ }^{1}$ was intended to cure such situations, and The Conditional Sales Act ${ }^{2}$ was intended to extend the protection. Therefore, these Acts only apply to cases where one person has possession, but his title is limited or encumbered.

I am going to mention some cases where a bill of sale or chattel mortgage need not be registered, but to my mind any transaction important enough to be brought to a solicitor is important enough for the preparation and registration of a bill of sale or chattel mortgage, so as to avoid any possible doubts as to whether the transaction is covered by the Act.

The operative section of The Bills of Sale Act avoids an unregistered sale or an unregistered mortgage against the protected classes of persons unless the sale or mortgage is accompanied by an immediate delivery and an actual and continued change of possession of the chattels sold or mortgaged.

Immediate delivery appears to mean delivery which is made as soon after the sale is completed as the circumstances admit. ${ }^{3}$

It appears that the actual and continued change of possession requires more than a change of possession as between the parties. Most of us will be familiar with the case of Dominion Lumber Company v. Alberta Fish Company." In that case, lumber was sold and moved into a railway right of way which abutted on the vendor's millyard and was not divided from it by a fence or other visible boundary. Mr. Justice Walsh held that the sale was void as against an execution creditor because there was nothing to show third parties that ownership had passed.

There is authority for the proposition that a creditor who knows of a change of possession is not protected by the Act, but under the present Act, change of possession must be open and reasonably sufficient to afford public notice there-

1R.S.A. 1955 c. 23.

2R.S.A. 1955 c. 54.

3Cockburn v. Jeannotte [1942] 2 W.W.R. 314-commenced to move chattels a day or two after the sale - void.

$4[1921] 3$ W.W.R. 619.

*A panel discussion presented to the meeting of the Alberta Section of the Canadian Bar Association, held at Edmonton in January, 1958. Members of the panel were: W. F. Bowker, Q.C., LL.M., Dean of the Faculty of Law, University of Alberta; Eldon Foote, B.Sc., LL.B. of Bryan, Foore, Andrekson and Wilson; J. M. Hope, B.A., LL.B., of Milner, Steer, Dyde, Massie, Layton, Cregan and Macdonnell; and W. H. Hurlburt, B.A., LL.B. of Kane, Hurlburt and Kane. 
of, and it may therefore be that even a creditor who knows of a change of possession which is not public, will be able to take advantage of the Act.

There is authority for the proposition that the Act does not apply where the goods or chattels are in possession of a third party in his own right, as in the case of a holder of a possessory lien on the chattels.

The operative section avoids sales and mortgages. The terms are very broadly defined, and it is advisable to look at the Act to consider whether any transaction must be registered where any interests in chattels become vested in some person in whom it was not previously vested. There is, however, some authority for the proposition that the definition does not include a gift. In Standard Trusts Company v. Hill ${ }^{5}$ Beck, J.A. delivered the judgment of the majority of the Alberta Court of Appeal holding that where there had been a gift of an automobile from a husband to his wife the seizure under writ of execution against the husband was valid. The Bills of Sale Ordinance he stated did not apply to this case because the words "Every sale . . . not accompanied by immediate delivery and followed by an actual and continued change of possession of the goods and chattels sold" refer only to assignments or transfers by way of sale.

So far as the Act is concerned, it would appear that if you wish to defeat your creditors, you must do it by a registered instrument, or you must not take money for doing it.

It should be observed that a sale does not include an assignment for the general benefit of creditors or a transfer of goods in the ordinary course of any trade or calling. It should also be observed that a mortgage does not include corporate securities contained in trust deeds, bonds, debentures or security taken under The Bank Act or power of distress. Therefore none of these securities needs to be registered as a chattel mortgage.

At this point I should mention a possible trap for persons disposing of goods. Not only must a conditional sale agreement or lien note be registered, but also any bailment where it is intended that property in the goods shall eventually pass to the bailee on the payment of purchase money or the performance of some condition. This appears to include a hire purchase agreement or a rental with an option to buy. It seems that if you merely rent chattels to a person there is no obligation to publish the fact that he has no title whatsoever, but if you give him a greater right, namely, the right to purchase the chattels, the document will then be void unless registered.

There is a further trap for the unwary, or possibly only unlucky, purchaser, in the Conditional Sales Act. Under Section 9(2), if a vendor marks on any goods his name, address and the information that the goods are his property until paid for, then he need not re-register when the goods are removed to another district. Section 11 goes further, ,although it only applies to manufactured goods and can be taken advantage of only by persons who have an of- 
fice in the Province. Under this Section, it is only necessary for the vendor to have his name on the chattel in order to avoid any registration whatsoever.

There does not appear to be anything in Section 11 which requires an address to be given or any statement to be made that the goods are not paid for, so that it would appear to be necessary to consider any name attached to any portion of the car, or at least any integral portion, to constitute a possible defect in the title of the apparent owner.

In a recent case, Traders Finance Corporation Limited v. Williams $\&$ Lange," the Supreme Court of Canada held that it was sufficient to satisfy a substantially similar provision in the Saskatchewan Act, that the vendor's name appear on the cowl of the car, which is the partition between the seating portion of the car and the portion containing the engine. The name was visible only when the hood of the car was lifted, but this was sufficient. It appears that the words in the section do not mean attached so as to be plainly visible from the outside. While the cases do not say so, the purchaser should "get out and get under", as the song goes, in case there is a name attached to the underneath portions of the car which would be plainly visible to a person viewing the car from underneath.

The cases seem to say that the name shown must be the proper name. It appears, for example, that "Mason \& Risch" is not sufficient to protect The Mason \& Risch Company Limited", that "Cockshutt" is not sufficient to protect The Cockshutt Plow Company, ${ }^{8}$ that "L. M. Ericsson Tel. Mfg. Co. Buffalo, N.Y." is not sufficient to protect the L. M. Ericsson Telephone Manufacturing Company. ${ }^{.}$Further, there is a recent judgment of Mr. Justice J. O. Wilson of the Supreme Court of British Columbia ${ }^{10}$ construing somewhat similar provisions in the Manitoba Act, which indicates that the word "Chevrolet" is not sufficient to protect the vendor of a motor vehicle of that make. However, it may be that the requirement will be enforced strictly only against corporations, because there is a rather elderly decison of the Ontario Court of Appeal which indicates that "Geo. Wettlaufer" is sufficient for the protection of a vendor by the name of George Wettlaufer."

Further problems arise if the original purchaser is not considerate enough to preserve the written or attached name. In the Wettlaufer case and also in a later decision of the same court ${ }^{12}$ it was held that the vendor is not under any duty to foresee the removal of his name, or to take any care to see that it is not removed. In the.Wettlaufer case, the vendor was aware that the purchaser was going to have the vehicle painted, but was not bound to do anything to see that his name, which was painted on it, would be visible thereafter.

There is a provision in the Act subjecting the purchaser to a penalty for

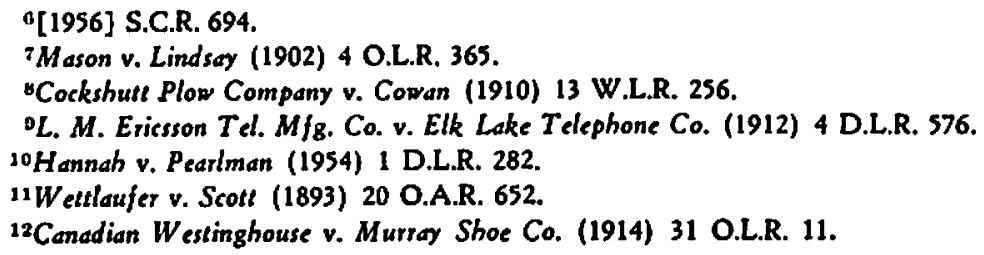


removing the vendor's name. The penalty is only $\$ 500$, and a purchaser might think it worth while taking the chance in order to pocket thousands of dollars.

Dealers in cars seem to be getting into the habit of having their names attached to the rear of the car when it is sold. Under the Act, I do not know of any reason why this would not be sufficient to protect the vendor's claim, and therefore to represent a possible defect in title, which might have to be cleared up by enquiry. Further, I have seen a car with the words "Ron $\&$ Doris" in luminous tape on the back bumper. I do not suggest that these words constitute a defect in title, but you will see that there are interesting possibilities.

In most cases it would be a useful and entirely effective precaution to attach the name of the vendor to the goods sold. It is advisable, however, also to register the documents so as to reduce the possibility of difficulties arising.

The Acts do not invalidate bills of sale or chattel mortgages or conditional sale agreements as between the parties, except in the case of mortgages of growing crops, which are avoided unless they come within certain specified cases.

Under The Bills of Sale Act, a sale or mortgage not accompanied by delivery and change of possession or by properly registeted instrument is void as against all persons who become creditors before registration; and registration means proper registration under the Act, so that the terms actually include all creditors. The situation is different under The Conditional Sales Act, as conditional sale agreements are void as against judgments, executions or attachments.

The consequences of holding a bill of sale or chattel mortgage void against all creditors, including simple creditors, have not yet been fully worked out. It is fairly clear that an execution creditor is entitled to exercise his right notwithstanding the invalid bill of sale or chattel mortgage. What is not so clear is what the rights of simple creditors are.

Our own Court of Appeal has indicated ${ }^{13}$ that, notwithstanding that the bill of sale is void as against simple creditors, such creditors really do not have any rights until their claim is reduced to judgment and a writ is issued, and then only if nothing has intervened to change the situation. The court said that a simple creditor is not entitled to bring an action for a declaration that the bill of sale or chattel mortgage is void. The Court of Appeal of Manitoba ${ }^{14}$ on the other hand has granted a declaration that a bill of sale was void, and granted it upon action brought by a simple creditor suing on his own behalf and on behalf of all creditors, there being no proof that there were any other creditors. The Court of Appeal of Saskatchewan'" has held that a creditor who was a simple creditor at the time of the sale is entitled to have the chattel seized and sold after he obtains his execution, notwithstanding the sale.

With regard to conditional sales agreements, there is nothing in the Act to say when judgment, execution or attachment must have issued. Unfair

13 McCabe v. Coste [1922] 3 W.W.R. 465.

14 Kippan v. McCan [1924] 1 W.W.R. 65.

1s Mickelson v. Nash-Simington Company, Limited [1923] 3 W.W.R. 843. 
though it may seem, it would appear that the conditional sale agreement may be invalid as against judgments or executions issued prior to the delivery of the goods, though how the creditors can have been prejudiced in such a case it is difficult to determine.

I would think that in the case of eicher a chattel mortgage or a conditional sale agreement, the right to contest the instrument must arise before the sale has been effected under this instrument; that is to say, in the case of a chattel mortgage that a simple creditor must have a claim against the debtor before the chattels are sold under the chattel mortgage; and in the case of a conditional sale agreement, there must be a judgment, execution or attachment in force before the chattels are sold in proceedings to enforce the conditional sale agreement. If the mortgagee or conditional sale vendor forecloses or takes the chattels in satisfaction of its claim, it would still appear to me that any claim arising after the time when that was done would not be effective. In each of these cases, I would think that the instrument must have performed its function completely once the foreclosure or sale has taken place, but I do not know of any authority on the point.

2. Relative merits of employing a Conditional Sale contract or granting a Bill of Sale and taking a Chattel Mortgage back.

As practising lawyers we are often faced with the question whether a chattel should be sold by a conditional sale contract or by the vendor granting a bill of sale and then taking a chattel mortgage back to secure the unpaid balance. Let us examine the position from various points of view.

Firstly, an examination of the Conditional Sales Act reveals that Section 19 of this Act applies to either of these methods so that a vendor would be precluded from seizing and selling goods and then looking to his buyer for a deficiency. From this point of view it would not matter which method was employed.

An examination of the Exemptions Act ${ }^{1 n}$ reveals that Section 4, Subsection (1) permits a defaulting debtor to claim an exemption for certain goods that are under a chattel mortgage. By using the bill of sale and chattel mortgage method therefore a person may run the risk of having his buyer later claim the chattels as exempt. It should be noted that under these circumstances the chattel mortgage is not invalid in the sense that the mortgagor cannot seize, since a seizure may be made and the onus is on the mortgagor to claim the exemption. This view is based on the wording of Section 4(1) which says:- "Any person ... shall ... have the right to claim as exempt from seizure and from sale any such chattels covered by the mortgage ...." The case of Bowyer v. Wiley ${ }^{17}$ seems to settle this point that a seizure may be made of an exempt chattel and it is up to a mortgagor to claim the exemption. Now it might well be asked whether a vendor, who is in form a mortgagee, having made a seizure, is precluded from then suing for the balance owing and yet his purchaser, who is in form a mortgagor, can claim the exemption so that the vendor (mortgagee

16R.S.A. 1955 c. 104.

17[1948] 2 W.W.R. 91. 
in form) has lost all his remedies. In the Bowyer v. Wiley case our Court of Appeal upheld the right of the mortgagor for a claim for exemption but held that the mortgagee could get judgment on the covenant in the mortgage. Our Court of Appeal in this case however does not appear to have considered the effect of Section 19(4) of the Conditional Sales Act and had it considered this subsection it might well have held that the right to sue on this covenant had also gone. Therefore on the present standing of the case law it would appear that a person could get a judgment on the covenant in a chattel mortgage notwithstanding the fact that he had seized. Moreover, it is difficult to reconcile such a judgment with Section 19, Subsection 4 of the Conditional Sales Act. There is also another interesting point arising from Bowyer v. Wiley in light of the Court's view in the case of Baxter v. Friendly Credit Corporation Lid..$^{18}$ The Court in the Bowyer v. Wiley ${ }^{12}$ case might properly have held that the transaction was in fact a conditional sale, that it therefore was not a chattel mortgage within Section 4(1) of the Exemptions Act and therefore that there would be no exemption and since the mortgagee was a mortgagee in form only but in fact a conditional vendor he was entitled to sell under his seizure but his right to sue had gone by virtue of Section 19 of the Conditional Sales Act.

It might also well be asked whether or not it would be wise to take a waiver of the provisions of Section 4(1) of the Exemptions Act if one is acting for the vendor in using the bill of sale with chattel mortgage back method. We doubt very much if this question of waiving the provisions of this Section has been seriously considered by the practising members of the profession and would refer the members to such cases as British American Oil v. Ferguson $^{10}$ and Mutual Life Company of Canada v. Marks and Leavitt ${ }^{20}$ for an excellent discussion on the question of waiving provisions of statutes. It would appear from these two cases that it would be necessary for the purchaser (mortgagor) to have independent legal advice so that he fully understands the protection that is given by this section and that any waiver should be contained in a separate document. Since we are unaware of any case directly on the question of waiving Section $4(1)$ of the Exemptions Act we are at this point not prepared to say whether or not it may be validly waived.

Thirdly let us consider the straight conditional sales method, and the bill of sale with chattel mortgage back method in the light of the Workmen's Compensation Act. In this connection we have the recent case of Workmen's Compensation Board v. United States Steel Corporation ${ }^{21}$ which has now established that a Workmen's Compensation claim does not have precedence over a conditional sale contract. The Court in this case held that a conditional sale contract does not come within any of those categories listed in Section 77(5) of the Workmen's Compensation Act" nor is it "property of

\footnotetext{
28(1952) S W.W.R. (N.S.) 135.

${ }^{10}$ (1951) 1 W.W.R. (N.S.) 103.

${ }^{20}[1939] 1$ W.W.R. 530.

21 (1956) 18 W.W.R. (N.S.) 403.

22R.S.A. 1955 c. 370 .
} 
an employer" within the meaning of Section 77 (4) nor are chattels contained in a conditional sale contract "goods and chattels" within the meaning of that Act.

What is the position of the two methods in respect of a landlord's claim? The Seizures $\mathrm{Act}^{23}$ makes it clear that a landlord can distrain on mortgaged goods located on the premises, that he will have priority over the mortgagee and that this is so even though the mortgage was given first. Under the Seizures Act a landlord can also distrain on goods that are on the premises which the tenant is purchasing under a conditional sale contract. However, in the case of goods the tenant is purchasing under a conditional sale contract the landlord will not have priority over the conditional vendor. The priority of the conditional vendor over the landlord appears to be abundantly clear in the wording of the Seizures Act itself which in essence says "interest of the tenant in such goods on the premises". The lack of registration of a conditional sale contract makes no difference to the conditional vendor's priority since a close examination of Section 3 of the Conditional Sales Act will disclose that a landlord is not included in the list of those parties who may claim the protection of the Conditional Sales Act if registration is not completed. ${ }^{2.3}$ Once again an interesting question is raised in light of Baxter v. Friendly Credit Corporation Limiled and Personal Loan \& Finance Company v. Kenned ${ }^{23}$ where in fact a person might be a mortgagee in form but in substance a conditional vendor. Under these circumstances the mortgagee in form would undoubtedly ask the court to find that he is in essence and in substance a conditional vendor and should accordingly on the basis of the Baxter case and the Personal Loan case have priority over the landlord. The court hearing this argument might well adopt the attitude that it was the mortgagee who elected the form of the sale and having made his election he could not now seek the assistance of the court. However, we are unaware of any reported case on this point.

The two methods should also be considered in the light of the provisions for registration. The Bills of Sale Act provides in Section 3(2) that a chattel mortgage shall be effective only from registration thereof, whereas under the Conditional Sales Act there is complete protection to the conditional vendor for the period allowed for registering the conditional sale contract and this view has been substantiated by the recent case of Klimove v. G.M.A.C. and Dubuc. ${ }^{2 \mathrm{~s}}$

In summing up it would appear that if a person wishes to sell an article and retain title as security for the payment of all or a portion of the purchase price he would be better off to sell by way of conditional sale contract rather than give a bill of sale and take a chattel mortgage back. A conditional vendor cannot escape the provisions of Section 19 of the Conditional Sales Act in either case; the use of the conditional sale method avoids the problems under the Exemptions Act and the Bowyer case, and he would retain

23R.S.A. 1955, c. 307

24The view that the landlord has priority over a mortgogee is substantiated by the case of Stott v. Heninger [1935] S.C.R. 408.

${ }^{25}[1948]$ I W.W.R. 318.

${ }^{26}(1955) 14$ W.W.R. (N.S.) 463. 
priority over the Workmen's Compensation liens and landlord's claims as well as having the advantage referred to in respect of registration.

There is one other aspect that is not completely discussed in the foregoing consideration of the two methods which may deserve comment. A person may wish to borrow money and give a chattel mortgage on an article that is known to be exempt from seizure. As we have seen this might well be loaning money on no security whatsoever since the mortgagor might claim the exemption. One might be inclined to advise the lender to take a bill of sale on the exempt article and then sell it back to the borrower on a conditional sale contract. On the face of it the borrower could not claim an exemption and the lender would be entitled to the priority advantages earlier mentioned; however, prior to adopting such a method, one should carefully examine the Baxter case and the Personal Loan and Finance case, earlier cited, since there is a distinct danger that the lender might lose his security in this fashion and also lose it against subsequent purchasers and mortgagees in that the combination of bill of sale and conditional sale contract might be interpreted as being, in pith and substance, a mortgage and since the affidavit of bona fides would not be completed in accordance with that required in a chattel mortgage the lender instead of bettering his position might be worsening it. ${ }^{2 \pi}$

\section{Form of Bills of Sale, Chattel Mortgages and Conditional Sale Agreements}

(a) Description of Goods

Both the Bills of Sale Act and The Conditional Sales Act for this Pro. vince require that the description of the chattels be such that "... the same may be readily and easily known and distinguished."

The purpose of both these statutes and the requirements as to description of the chattels is to prevent creditors being defrauded. The description is to afford facilities for unsecured creditors to distinguish between goods of their debtor which are encumbered from those which are as yet unencumbered. It is to protect persons dealing with him and giving him credit upon the faith of the property of which he was in open possession being, as it appeared to be, his own property. These sections were not enacted for the purpose of enabling the mortgagee to know and distinguish the goods upon which he has agreed to accept the security taken. Nor are they to enable a stranger to the transaction, or the court upon a question arising merely by looking at the description in the document to distinguish what goods were encumbered from other goods of the debtor. They are to enable prospective purchasers or persons contemplating becoming his creditors to ascertain what part, if any, of the goods being in his possession and apparently his own is to any, and if any, to what extent encumbered by assignment to a stranger or to a preferred creditor so as to be removed wholly or in part from liability to unsecured creditors. ${ }^{20}$

Whether or not a description is sufficient to enable the goods mortgaged to be distinguished within the meaning of the statute is always a question of fact

27See too Scott v. Moose Jay Motors Led. et al [1924] 2 W.W.R. 1234 (Sask. C.A.).

28See s. 5 of the Bills of Sale Act and s. 3 of the Conditional Sales Act.

${ }^{29}$ This purpose was outlined by Gwynne J. in Hovey v. Whiting (1888) 14 S.C.R. 515. 
and not of law. Recognition of this principle was given by the Supreme Court of Canada in Hovey v. Whiting ${ }^{20}$ and has been approved in many subsequent decisions.

What might constitute a sufficient description in one case might not be sufficient in other circumstances, e.g. "one elephant" in Alberta might be sufficient, but otherwise in Rangoon.

Many chattels have no serial number to identify them. Many in fact cannot be sufficiently described on the face of the docuument so that without other enquiry the property could be identified. This situation was recognized in McCall v. Wolff $f^{30}$ by the Supreme Court of Canada.

.. . this need not be such a description as that with the deed in hand without other enquiry the property could be identified but there must, in my opinion, be such material on the face of the mortgage as would indicate how the property may be identified if proper inquiries are instituted....

And Strong $\mathrm{J}$. in the $M c$ Call case referred to an American decision wherein it was stated:

... it is sufficient that the mortgage points out the subject matter of it so that a third person by its aid, together with the aid of enquiries as the instrument itself suggests may identify the property covered.

The principle was approved in Hovey v. Whiting.

But what enquiry is contemplated or is the third person bound to make? It is difficult to derive any rule from the cases. In Jordan v. J. I. Case Threshing Machine Co.," it was held that there was no duty upon the purchaser to search the registry and that the failure to search did not alter or prejudice his position. This was approved in Alberta in Re Seizures Act, I.A.C. v. Whiting. ${ }^{32}$ However Eberts J.A. in Brandon v. Plimley ${ }^{33}$ in the B.C. Court of Appeal seems to place some weight on the fact that the purchaser might have searched the registry.

What circumstances affect the sufficiency of a description? The rarity of an article in a particular area may reduce the descriptive detail otherwise necessary. ${ }^{3-4}$ Special knowledge which a creditor possesses and which bears upon some descriptive detail contained in the document (e.g. location) may supplement a description which would otherwise be inadequate. ${ }^{35}$ The descriptive detail required in a chattel mortgage may be something less than that required in a conditional sale agreement. ${ }^{313}$ The reason for this is that in the former the chattels do not change hands and consequently the circumstances of their possession and location furnish means of distinguishing them from others of the same kind.

When the subject matter of the sale consists of a multitude of items such as stock in trade, it is not essential that an inventory of the goods be taken and

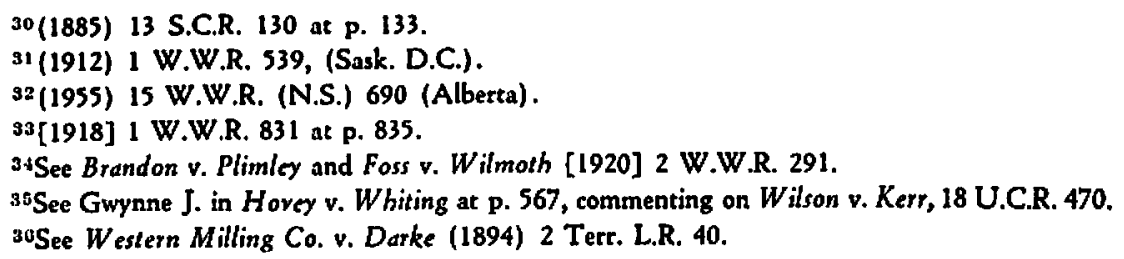


listed in the lien or mortgage document. If the goods are the only ones of their kind owned by the debtor, then it is sufficient if they are so described, e.g. "all of the sheep owned by A", "all of the stock in trade owned by A".

If the goods are the only ones of that description at a particular location, then it is sufficient to so describe them and designate the location.

In either of the foregoing cases, the creditor does assume the risk, should the occasion arise, of establishing that particular items were included amongst those items described in the document as "all ...".

Gwynne J. in Hovey v. Whiting laid great stress on the sufficiency of a description which is as to "all of A's stock in trade, etc." but he took the view that to describe goods by naming a locality is the "least efficient mode possible" and in many cases utterly useless. He cites as his reason the fact that the locality in which the goods were at the time of the mortgage may be wholly changed by the time the question of their identity under the mortgage arises.

With respect, it is difficult to find any distinction in principle between the sufficiency of description in the two cases. In the former case, the debtor may acquire additional goods of like kind, in which event it would likewise prove necessary to call parol evidence to establish the goods. The distinction may possibly be that in the former case, e.g. "all of the sheep", the intending purchaser is immediately put on his inquiry, whereas in the case, "all of the sheep on Blackacre", he is not put on his inquiry if they are sold to him from a different location and he is unaware that they had been on Blackacre.

Because of this inherent weakness in a general description, i.e. confusion arising through the addition or substitution of items of like kind or by reason of a change in location, it is advisable in a chattel mortgage to supplement such a description with clauses relating to progeny and after acquired property. ${ }^{37}$ Clauses relating to after acquired property have been restricted in their application by the ejusdem generis rule and are construed strictly. Inclusion of such clause avoids the difficut or impossible problem of subsequent positive identification by parol evidence. The standard chattel mortgage form usually contains such clauses. ${ }^{38}$ Baton, however, suggests that such a clause may be effective as between the parties but not as against third parties.

Both the Bills of Sale and Conditional Sales Acts define a motor vehicle as including:

... every vehicle propelled by any power other than muscular power but does not mean aircraft, tractors, whether equipped with rubber tires or not, traction engines and such vehicles as run only upon rails or tracks.

And both statutes require that the description of a motor vehicle "... shall include the serial number of the motor vehicle."30 In the Alberta case of Re Seizures Act -I.A.C. Led.v. Whiting ${ }^{40}$ in the document, the last figure in the serial number of a Ford car was incorrectly shown as an " 0 " and should have been a

\footnotetext{
${ }^{37 S e e}$ Goldie y. Taylor (1896) 2 Terr. L.R. 298, Dom. Reg. v. Hall and Fairveather 8 D.L.R. S77.

s8Baron 6e O'Brien on Bills of Sale (1927) pp. $13-16$.
}

39S. 11 (2) of the Bills of Sale Act; s. 5(2) of the Conditional Sales Act.

'OSupra, footnote 32. 
"9". Buchanan C.J.D.C. held that the description was defective and stated: "In the year 1953 in Alberta serial numbers of cars had become and now are the essential and distinguishing item in the description of any car"."

Such a strict view was not taken in 1920 in the Saskatchewan case of Foss v. Wilmot $h^{34}$ where an extra figure in the serial number of a "Hudson Roadster" did not prove fatal since it was then the only automobile of its kind in the vicinity of Regina. ${ }^{\text {t2 }}$

Special provisions are to be found in the Bills of Sale Act regarding the chattel mortgage security which may be taken on growing crops. ${ }^{33}$ Such a chattel mortgage may not exceed $\$ 500.00$, may only validly secure the purchase price of seed grain or of necessaries as defined in the Act. The description should set forth: the nature of the crop, e.g. wheat, etc.; the location of the land (e.g. legal description); the acreage; whether the crop is growing or is "to be grown"; and, if so, when.

\section{(b) Consideration}

Although neither the Bills of Sale Act nor the Conditional Sales Act require in so many words that the consideration is to be set out, both Acts require that the sale, if not accompanied by an immediate delivery, shall be in writing and shall be accompanied by an affidavit, the terms of which contemplate that there shall be a true consideration expressed in the document. Secs. 8, 9 and 10 of the Bills of Sale Act prescribe that the affidavit of the grantee shall truly set forth the terms or substance of the agreement, including the nature, extent and amount of any indebtedness or liability thereby secured. Sec. 4(3) of the Conditional Sales Act requires that the affidavit of the seller state that the document "truly sets forth the agreement" entered into between the parties.

It. has been held that unless the consideration is truly expressed in a chattel mortgage, it shall be absolutely void as against creditors of the mortgagor. ${ }^{4+}$

\section{(c) Terms of Repayment}

Care should be taken that the terms of repayment are not in conflict with the provisions of other statutes. Those statutes which affect the terms of repayment as expressed in a chattel mortgage or conditional sale agreement in Alberta are:-

The Interest $A c t^{43}$-provides that except in real estate mortgages the interest must be expressed in a rate per annum (or greater period). Otherwise no interest exceeding $5 \%$ per annum shall be chargeable, payable or recover-

"1ibid p. 695.

12However, there was then no statutory provision comparable to s. 11(2) of the Bills of Sale Act or s. $5(2)$ of the Conditional Sales Act.

4 Sec. 35.

${ }^{44}$ Henton v. International Harvester [1926] 2 W.W.R. 118 (Alta. Court of Appeal). In that case the document specified an indebtedness of $\$ 2,674.50$, but omitted to specify a further indebtedness of $\$ 98.00$.

45R.S.C. 1952 c. 156. 
able. Sec. 3 provides that if no interest rate is expressed, then the rate shall be $5 \%$ per annum.

The Small Loans $A c t^{4 n}$-This Act is designed to control the practice of money lenders and loan companies who charge a nominal interest rate but add charges against the borrower as discount, commission, brokerage, recording fees, etc., and thereby render the provisions of the Interest Act ineffective. The Act applies only to money lenders and loan companies (as defined in the Act) and to loans of $\$ 500.00$ or less. The Act prohibits charges to a borrower which exceed $2 \%$ per month for a loan up to 15 months; $1 \%$ per month for a loan over 15 months. The Act does not apply if the rate does not exceed $12 \%$ per annum. Infraction of this Act is punishable by a fine and imprisonment.

The Credit and Loan Agreements Act"-This Act applies to "time sales" where the total price exceeds $\$ 100$ and is to be paid within a fixed period by 3 or more payments and to "loan agreements" i.s. chattel mortgages or bills of sale, etc., evidencing or securing a loan of money. The Act is designed to cover sales or loans to a consumer as distinguished from a manufacturer, distributor, wholesaler, or retailer in the course of business. The Act does not apply to loans by lending institutions, to loans under the Small Loans Act nor to loans where the whole cost of the loan is expressed as a rate per centum per annum on the amount actually advanced if no other charges of any kind are to be paid by the borrower. If a transaction falls within the ambit of this Act, careful attention should be given to its provisions regarding terms of repayment and details of sale price and charges. Failure to comply with the Act is punishable by a fine or imprisonment.

The Vendor's and Mortgagees' Costs Exaction Act" -This Act makes null and void any agreement by a party to a chattel mortgage or conditional sale agreement for the sale of personal property which purports to make that party liable to pay any fees, charges or costs other than:-

i. court costs

ii. costs and disbursements relative to the issue and service of a Statement of Claim

iii. costs relative to a land mortgage.

It is an offence punishable by a fine and imprisonment for any person to demand costs which are prohibited by this Act.

\section{(d) Signature}

Both the Bills of Sale Act and the Conditional Sales Act refer to execution of the document by the debtor only. Sec. 6 of the Bills of Sale Act refers to the registration of the document within 30 days from the date of its execution and in subsection 2 refers to execution "by the grantor" only. Sec. 7 , which provides for an affidavit of execution, refers only to execution

48R.S.C. 1952 c. 251.

47R.S.A. 1955 c. 66.

18RS.A. 1955 c. 357. 
by the "grantor or grantors". Sec. 3 of The Conditional Sales Act postpones a vendor's property rights to those of third parties "unless the sale or bailment with such agreement proviso or condition is in writing signed by the buyer or bailee or the agent of the buyer or bailee . ..." Sec. 4 of the said Act does make it a prerequisite of registration that there be an affidavit of the seller or bailor.

Conditional sale contract forms, in general use, often provide for execution by both the vendor and the purchaser and in the contract, not only does the purchaser promise to pay for the goods, but the vendor covenants to supply the goods. Strictly speaking a conditional sale contract need not contain a covenant to supply by the vendor. If the contract is under the seal of the promisor only, his promise to pay is an absolute one independent of the agreement of the conditional vendor, and the vendor has the option of taking advantage of the promise or not. ${ }^{\text {th }}$

\section{(e) Affidarits of Execution and of Bona Fides}

For registration to be effective, every conditional sale agreement and every bill of sale or chattel mortgage registered must have attached to it an affidavit of bona fides. Every bill of sale must also have an affidavit of execution unless it is executed by a corporation. In the past, and probably even today, the rigid and technical requirements of the law with regard to these affidavits, and the regard had to form at the expense of substance appear more suitable to the common law as it was in medieval times than to a modern system of laws. As a result, this is a fruitful field for litigation, and also for claims against solicitors for professional negligence.

The requirements of the Bills of Sale Act concerning the affidavit of execution are quite simple: the affidavit must prove the execution; it must be made by the attesting witness; it must identify the bill of sale; and it must state the date of execution. If there is more than one grantor, these particulars must be given for each and there may be more than one affidavit.

The Acts prescribe who may swear the affidavit of bona fides, and I shall not go into that point here. It should be noted, however, that the Bills of Sale Act provides that an affidavit made by an agent or by an officer or employee of a corporation must state that the deponent is aware of the circumstances connected with the bill of sale and that the deponent has a personal knowledge of the facts deposed to, and failure to do so may invalidate the document. It is good practice to put a similar statement in the affidavit of bona fides attached to a conditional sale agreement.

The Conditional Sales Act prescribes only one form of affidavit of bona fides, and it is difficult to go wrong if one faithfully copies the words of the section, but many people do not follow this simple and salutary rule. The situation is somewhat more complicated under the Bills of Sale Act, as three different sections deal with the different categories of transactions, and it is necessary to choose the proper category. Choosing the right category may in itself be a $\$ 64,000$ question with a slightly different twist: if you win,

49See Xenos v. Wickham (1867) L.R. 2 H.L. 296. 
you break even, if you lose, you lose your $\$ 64,000$ and there is no Cadillac as a prize for a good try.

For example, suppose that the arrangement is that the moneys will be advanced when the mortgage security is registered. I think that that would be a present advance, but I do not know of any authority for that proposition. Suppose you go on to say that you are then going to hold the money back for 21 days to protect against other registrations which might be possible. Is that a present advance? Suppose then, after the document is registered, the mortgagor says that he does not want the money for a week or two or a month or two. Is it still a present advance? In any of these cases, it might be argued that because the money did not change hands when the mortgage was executed, it was rather a case of future advances to be made under an agreement. If you pitch on the wrong section, you may lose your security.

The courts at various times have set aside registered documents because of various errors in the formal parts of the affidavits, for example failure on the part of the commissioner to sign the affidavit on the registered copy although he had signed the original. They have, however, indicated that the strict rules as to the swearing of affidavits prescribed by the Rules of Court do not apply; and have refused to set aside documents because the date in the jurat was wrong; because the signature of the Justice of the Peace appeared above instead of below the jurat (though this was the case of an affidavit of execution and the Court indicated that it might have been otherwise in another type of affidavit); because the name, address and occupation of the deponent were omitted; because the jurat did not state that two deponents were severally sworn; because of an omission to strike out a statement that the deponent was an agent where he was actually the mortgagee. It is fatal if the affidavit of bona fides is sworn before the document is signed; and it is fatal if it should appear that an affidavit though apparently sworn, was really not sworn.

The courts have also set aside numerous documents because of failure to make proper statements; because of omission to put the date of execution in the affidavit of execution; because the deponent failed to allege personal knowledge when required to do so; because the deponent, who was president of the grantee company named in a chattel mortgage, said that the mortgage was not for the purpose of enabling "me this deponent" to hold the goods against the creditors of the bargainor, where she should have said the "bargainee"; because the affidavit stated that the "agreement . . . is bona fide" instead of "is entered into bona fide" (though there seems to be a conflict on this point); because the affidavit said that the registered copy was a true copy of the original instead of saying that it truly set forth the agreement between the parties. In one case, a Court went so far as to set aside a document because of a reference to "the creditor" of the mortgagor instead of "the creditors".

These cases were all decided before the adoption of the uniform Bills of Sale Act, and it is not too clear at the present time whether or not they 
would all be decided the same way under that Act, though they would still seem applicable to the Conditional Sales Act, which has no curative provision. The curative section in the uniform Bills of Sale Act is quite broad, as it provides that no defect or irregularity in any affidavit accompanying a bill of sale invalidates or destroys the effect of the bill of sale unless, in the opinion of the court or judge before whom a question relating thereto is tried, such defect or irregularity has actually misled some person whose interests are affected by the bill of sale. To the untutored mind it might appear from this section that, so long as there was an affidavit of some sort, the document would not be set aside unless somebody was actually misled, and possibly that the person attacking the bill of sale would have to show that he himself had been misled, and to his detriment. However, doubt has been cast on this interpretation by the case of Kendrew v. Cushing in in our Appellate Division. In that case, a debtor, owing $\$ 1,800$, gave a chattel mortgage to secure $\$ 2,000$, the balance to be advanced. This mortgage should have been accompanied by an affidavit under Section 9, for a sum justly due or accruing due, as to the $\$ 1,800$, and by an affidavit under Section 8 , future advances to be made under an agreement therefor, as to the balance. The affidavit actually attached was on a stationer's form intended to deal with either of the two cases under Section 9, an amount justly due or accruing due, or an amount by way of present advance; and neither alternative had been struck out so that the affidavit said that the amount set forth as being the consideration "is an ascertained amount justly due or accruing due from the mortgagor therein named to the mortgagee therein named or that the amount set forth in the within chattel mortgage as being the consideration therefor is a present advance being made by the mortgagee therein named to the mortgagor therin named." The chattel mortgage was held invalid as against the trustee in bankruptcy of the mortgagor. Chief Justice Harvey said:

It is apparent that this (the statement in the affidavit) is no definite statement of what the Act requires and even if it were possible, having regard to the terms of the mortgage, to treat the second alternative as surplusage and adopt the first part, it is not a true statement for only $\$ 1,800$ is an ascertained amount and the stated consideration is the whole $\$ 2,000$, including possible future advances.

He then quoted the curative section in the uniform Act, and went on:

It is undoubtedly a very broad section but it certainly cannot be intended to cure a complex disregard of definite and specific provisions of the statute such as exists here.

I would not care to say whether the ratio of the case is that an untruth contained in an affidavit will be grounds to set aside the mortgage; or the making of an affidavit under the wrong section will be grounds to set aside the mortgage; or that a failure to strike out the alternative provision in the affidavit will be grounds to set aside the mortgage. I would be prepared to say that any solicitor who wishes to permit himself the luxury of making a mistake in an affidavit of bona fides had better be prepared to pay out his client's claim or go to the Supreme Court of Canada.

Kendrew v. Cushing has been applied in a Saskatchewan case, Adkins v. National Finance, ${ }^{\text {sh }}$ by Smith L.M. as authority for the proposition that a fail- 
ure to strike out either alternative was fatal, even in a case where no one had been misled - and it should be noted that in the Kendrew case there is nothing in the judgment to indicate that anyone was. It was also referred to by the Nova Scotia Court in Jollimore v. Bauld" where the alternative statements were present as two separate paragraphs, without even an "or" between them. The mortgage was set aside in that case also. A dissenting judge said that the ratio of the Kendrew case was that the affidavit was false. The majority said that, while the Kendrew case was distinguishable in point of decision, they adopted the general approach of the Court there.

Probably I should say at this point that there is no objection to having one mortgage secure more than one type of indebtedness, e.g. both an existing indebtedness and a present advance, but the affidavit must very clearly differentiate between the two and satisfy the statute with regard to each. It should also be noted that where a mortgage is bad with regard to one sum, it may nevertheless be held good in part if the two amounts are severable.

In passing, I should mention that in the case of a mortgage of growing crops, it is a fatal defect not to include in the affidavit of bona fides statements bringing the mortgage within the cases permitted by the Act.

To conclude, I would repeat again that the rules relating to these affidavits are extremely technical, and any time spent on the affidavit of bona fides is well spent from the point of view of protecting your client and of avoiding negligence actions resulting from errors. I feel annoyed every time I have to waste time on them, because I think the rules are arbitrary and very close to being nonsensical, affording no real protection to anyone with a legitimate interest, and imposing an unfair risk of loss on the conditional vendor, mortgagee or purchaser.

\section{Registration}

\section{(a) Place of Original Registration}

If an Itinerant Machine, i.e. motor vehicle, aircraft, trailer or oil well drilling equipment (definition is same in both Bills of Sale and Conditional Sales Acts), then whether it be a bill of sale, chattel mortgage or conditional sale agreement, it is to be registered within twenty-one days of the making of the instrument at the Motor Vehicles Branch in Edmonton. ${ }^{33}$

If other Chattels, then in the case of a condirional sale agreement registration shall be effected within thirty days from the time of actual delivery of the goods to the buyer or bailee in the registration district within which the buyer or bailee resides and in the registration district in which the goods are delivered."

In the Case of a Bill of Sale or Chattel Mortgage, registration shall be effected within thirty days from the date of its execution in the registration district in which the chattels comprised in the bill of sale are situate at the date of execution of the bill of sale."is

${ }^{52}[1950] 4$ D.L.R. 242.

siSec. 11 of Bills of Sale Act and Sec. 5 of Conditional Sales Act.

51 See Sec. 4 of Conditional Sales Act.

ss See Sec. 6 of Bills of Sale Act. 
(b) Re-registration on Removal into another District in the Province

These provisions apply only to chattels other than itinerant machines since there is a central registry for itinerant machines. Such registration on removal is only necessary where there is a permanent removal. In the case of a conditional sale agreement a copy of the conditional sale agreement and of the affidavit certified to be a true copy by the Clerk of the registra. tion district within which it was originally filed is registered in the registration district within which goods are removed within thirty days after the seller or bailor has received notice of the place to which the goods have been removed. ${ }^{56}$ The provisions in the Bill of Sale $\mathrm{Act}^{57}$ are the same except the certifying officer is the one in whose office the bill of sale was registered or was last renewed.

(c) Re-registration on Removal into the Province

I will deal first with itinerant machines. In the case of both conditional sale agreements and chattel mortgages, registration must be effected in the Motor Vehicles Branch within twenty-one days after seller or grantee receives notice of the permanent removal into Alberta. ${ }^{58}$

In the case of both a conditional sale and chattel mortgage, a copy of it and of all affidavits and documents accompanying or relating thereto, proved to be true copies by the affidavit of some person who has compared them with the originals, must be filed.

Oddly enough, the provisions in the Bills of Sale Act for registration upon removal into the province refer only to a mortgage. Presumably our Act makes no requirement for registration in the case of goods subject to a bill of sale which are removed into the province. Such being the case, a purchaser by bill of sale, but not in possession, even though he learns of the removal of the goods into Alberta, need not register. Since his common law rights are unimpaired by our statutes, no duty of registration is imposed upon him.

I should like to deal with two recently decided cases which involve contesting claims between the unpaid vendor or mortgagee outside the province and a bona fide purchaser in the province to which the goods were removed. In each case, the unpaid vendor and mortgagee registered his document after the sale to the bona fide purchaser but within the time limited to them by the Acts of the province to which the goods were removed. In both cases the claim of the bona fide purchaser was defeated.

In the case of Re Union Acceptance Corporation Limited, ${ }^{50}$ a decision of our Appellate Court, the facts briefly were that a finance company in Toronto took a chattel mortgage on A's Dodge sedan to secure $\$ 1,956$. The mortgage was entered into in Ontario. A brought the car to Alberta and sold to $B$ who in turn sold to $C$. Both $B$ and $C$ were bona fide purchasers without

snSec. 9 of Conditional Sales Act.

sisee Sec. 14.

skisee Sec. 14 of Conditional Sales Act and Sec. 15 of Bills of Sale Act.

so(1955) 16 W.W.R. (N.S.) 283. 
any notice of the finance company's mortgage. Approximately 6 months later the finance company learned that the car was in Alberta and within the prescribed $2 \mathrm{l}$ days filed the chattel mortgage in Alberta.

It was held that since the mortgage had been registered within the time prescribed by our Act, it is entitled to priority even against those who acquired title before the mortgage was registered in the province. In this case it was held that Section 3 of the Bills of Sale Act which provides that ". . and the sale or mortgage, and the bill of sale, if any, evidencing the sale or mortgage shall as against creditors and such subsequent purchasers or mortgagees take effect only from the time of registration of the bill of sale", is not of general application and does not apply to mortgages made outside the province.

Registration of the chattel mortgage in Ontario was not proved at the trial and it was argued that Section 7 of the Ontario Act provides that if the mortgage is not registered as provided by that Act, it is absolutely null and void as against creditors and subsequent purchasers, etc., in good faith. It was held (adopting the reasoning of Harvey C.J. in Cline v. Russell ${ }^{\text {so }}$ ) that the Ontario Section must be taken to apply only to subsequent purchasers and mortgagees in Ontario and not those who acquired their interest in this province.

In the case of McAloney v. McInnes and General Motors Acceptance Corporation, ${ }^{\text {,1 }}$ a decision of the Nova Scotia Court of Appeal delivered by Mr. Justice Doull, A purchased a car in B.C. under a conditional sale contract. It was not registered in B.C. as required by the B.C. statute. The car was subsequently removed by $A$ to Nova Scotia and sold to a bona fide purchaser. The vendor learned of removal and registered the conditional sale agreement in Nova Scotia within the time prescribed by the Nova Scotia statute. It was held that the conditional vendor was entitled to seize the car as against the bona fide purchaser in Nova Scotia. It was also held that the requirements as to registration in B.C. apply only to transactions within B.C. Had the car been sold to a bona fide purchaser in B.C. such a purchaser would acquire good title. However, when the car was removed to Nova Scotia, the common law rights of the vendor to possession of the car were not impaired by any provisions of the B.C. statute but were subject to those provisions in the N.S. Act relating to registration upon removal into that province. The N.S. Act required registration within 20 days after removal has come to his knowledge. The vendor had complied with this provision.

Reference is made in the McAloney decision to an earlier decision of the B.C. Supreme Court Trial Division - Hannah v. Pearlman ${ }^{02}$ - decided in 1954 by Mr. Justice Wilson. The facts of that case were similar to the McAloney case in that a car subject to a lien note in Manitoba was removed to B.C. and sold to a bona fide purchaser. Subsequently the Manitoba vendor learned of the removal to B.C. and he registered in B.C. within the 20 days after the removal came to his knowledge. The Court held, however, that the

${ }^{80}(1909) 10$ W.L.R. 666.

61 (1955) 37 M.P.R. 131.

G2[1954] 1 D.L.R. 282. 
purchaser in B.C. acquired good title on the grounds that the vendor had not complied with the terms of the Manitoba Act which requires that the goods have printed on them the manufacturers name, etc. In effect, Mr. Justice Wilson held that failure to comply with the requirements of the Manitoba statute made the conditional sale agreement invalid and destroyed his common law rights to the car as against everyone. By applying the law of Manitoba to a car in B.C. he was giving extra-territorial effect to the Manitoba law. ${ }^{\text {bs }}$

Right of a bona fide purchaser to acquire title during the period allowed vendor or mortgagee for original registration of the instrument.

As I have already outlined, the cases hold that where goods are removed into the province, a bona fide purchaser can acquire no title notwithstanding the fact that the document is not registered in this province if the vendor or mortgagee, as the case may be, registers within the time prescribed by our Act, i.e., 21 or 30 days from date of notice to him.

Similarly in the case of an original sale in this province by conditional sale agreement, a bona fide purchaser can acquire no title if the vendor registers within the prescribed time. These were the facts of the Klimove case, ${ }^{\text {b.1 }}$ a decision in 1955 of our Court of Appeal delivered by Mr. Justice C. J. Ford, now Chief Justice.

Such is not the case however on the original registration of a bill of sale. Sec. 3 (2) of our Act specifically provides:

The sale or mortgage and the bill of sale, if any, evidencing the sale or mortgage take effect as against creditors and such subsequent purchasers or mortgagees only from the registration of the bill of sale.

Subsequent purchasers or mortgagees are defined in Sec. 2 (a) of the Act to mean "persons to whom chattels are conveyed or mortgaged after the making of the sale or mortgage mentioned in Section 3", not, it should be noted, after the time limited for registration. Such being the case, a purchaser or mortgagee is at his peril as against bona fide purchasers, etc., until registration.

Mr. Justice C. J. Ford, in the Klimove case, held that the common law right of the vendor as owner of the goods or chattels is recognized by the statute, but its exercise against a purchaser or mortgagee for value without notice is subjected to the requirement of registration of the conditional sale agreement within the time limit.

The relevant section in the Conditional Sales Act is Sec. 3(1) where it provides that on a sale without registration as required, the seller is not permitted to set up any such right of property as against a purchaser or mortgagee of or from the buyer.

In the Klimove case, Mr. Justice C. J. Ford cited with approval Hulbert v. Peterson, and Reick v. Neeb, wherein the expression "subsequent purchasers"

03I respectfully submit that the decision is wrong in principle and I would commend to you an article by Jacob $S$. Ziegel which appears in (1954) 32 Can. Bar Rev. p. 900.

a.Klimore v. G.M.A.C. 14 W.W.R. (N.S.) 463.

G5(1905) 36 S.C.R. 324.

G6[1948] O.R. 459. 
was held to mean a purchaser after the expiration of the period specified for filing of the document, which would lead one to deduce that had there been no registration within the time, he would still have ruled in favour of the conditional vendor.

Having regard to the fact that the term used in our Conditional Sales Act is "purchaser" and not "subsequent purchaser", it is submitted that it is doubtful that those decisions have application to our present Conditional Sales Act. If our courts were to hold that Hulbert v. Peterson is applicable to our Conditional Sales Act, then it would follow that a bona fide purchaser during the statutory period would acquire no title even though the vendor never registered.

It is respectfully submitted that the Klimove case cannot be taken as authority for that proposition since in that case registration was effected within the period and adoption of the principle is merely obiter.

In Industrial Acceptance Corporation v. Munro, ${ }^{17}$ the Ontario Court of Appeal held that since the purpose of the Conditional Sales Act is to protect purchasers who acquire property on the faith of possession in the vendor, the words "subsequent purchaser" in Sec. 2(1) of that Act mean one who purchases at any time after the conditional sale and not merely one who purchases after expiry of the time for registry of the agreement.

It is still open to question, however, and it may be, in the light of the decision, that the problem can only be avoided by including a definition in the statute of the word purchaser.

\section{Remedies}

When can a mortgagee or vendor under a conditional sale contract invoke remedies? The contract governs this, generally speaking, very thoroughly. The most common one that occurs to us is a default in the payments which the mortgagor or conditional purchaser is obliged to make. In drafting the contract ourselves rather than using a form we should make sure that it contains an acceleration clause so that a default in one payment would permit proceedings for the full balance owing. Such an acceleration clause should be drafted in such a way that a conditional vendor or mortgagee can invoke the acceleration clause without having to give any notice of its exercise and might be to the effect that - "The balance of the unpaid principal and interest theron shall forthwith become due and payable without notice". In these days of rapid transportation it is sometimes difficult enough to contact a defaulting debtor on one occasion without having to contact him in order to give him notice of the exercise of a clause and then subsequently have to contact him again in order to serve him with a Statement of Claim. In respect of this point of having an automatic acceleration clause we would refer the reader to the recent case of $W$ alker v. Mason." There are many provisions which generally appear in the accepted forms such as bankruptcy, removal of chattels or even where the vendor or mortgagee deems itself insecure, which

G7[1950] O.R. 130.

${ }^{6 B(1957)} 21$ W.W.R. 8. 
permit the conditional vendor or mortgagee to invoke his remedy and none of these provisions should be overlooked in drafting a contract.

With respect to a vendor under the conditional sale contract there is, for practical purposes, nothing in the Exemptions Act that restricts him from exercising his remedies, because the exemptions set out in Section 2 of the Act apply (1) to a seizure under a Writ of Execution and (2) to the interest of a conditional vendor who elects to seize under the provisions contained in his conditional sale contract. We will not go further on the effect of Section $4(1)$ of the Exemptions Act ${ }^{16}$ relating to chattel mortgages and the Bowyer ${ }^{17}$ case other than to reiterate that a person might well borrow and give chattel mortgage security on an article he would later claim as exempt and thus in fact give no security for a loan from an unsuspecting benefactor (lender). This position might well be reviewed by our legislature in that it would appear to give an entirely unfair advantage to a borrower.

Speaking of a straight conditional sale contract (ignoring for the moment any effect of a promissory note) where property is reserved to secure a balançe of purchase price either by way of conditional sale contract or bill of sale with chattel mortgage back we have seen the effect of Section 19 of the Conditional Sales Act whereby such a conditional vendor or mortgagee is obliged to make an election as to whether he will sue on the covenant or seize the article. If he seizes he is then obliged to take satisfaction from the proceeds of the sale of the article, and has no remedy for the recovery of any deficiency notwithstanding the provisions of his contract. If he sues on the covenant and reduces his claim to a judgment he will, of course, have all the remedies for collection open to him as an execution creditor; however, should he after suing on the covenant in a conditional sale contract or a chattel mortgage and reducing his claim to judgment, seize under the Writ of Execution based on that judgment the article which was the subject matter of the conditional sale or chattel mortgage securing the purchase price he is then precluded from further collection remedies for any deficiency by reason of Section 19(3). Nowadays there is often a question of which law is applicable in such cases. For instance the Province of Saskatchewan has similar legislation to Alberta's Section 19 of the Conditional Sales Act in its Limitation of Civil Rights Act. $^{\circ 9}$ The Limitation of Civil Rights Act in the Province of Saskatchewan is slightly more severe from a vendor's point of view in that it contains no election but limits the vendor to repossession and sale of the articles being sold. In the case of Canadian Acceptance Corporation v. Matte, ${ }^{70}$ a Saskatchewan Court found that it was obliged to apply Manitoba law and we have a Saskatchewan Court permitting a judgment for a deficiency which it would not have awarded had it been applying Saskatchewan law. The defendant in the Matte case claimed the protection of the Saskatchewan Limitation of Civil Rights Act. However, the Court found that the contract having been made in Manitoba it was bound to apply Manitoba law and the defence failed.

In respect of this topic we must consider the more typical finance case.

69R.S.S. 1953 c. 95.

7022 W.W.R. 97. 
In a typical finance case we usually find that the finance company is a mere purchaser of paper. A dealer sells a unit on a conditional sale contract and takes as well a promissory note. The dealer is the vendor in the conditional sale contract and the payee of the promissory note. The instrument of primary indebtedness is the promissory note and the conditional sale contract is generally collateral security to the note. The dealer then sells the paper to the finance company and assigns the conditional sale contract and then endorses the promissory note to the finance company. Now the question arises as to whether the finance company may seize and sell the unit under the conditional sale agreement and yet successfully conduct a suit for the deficiency, making its claim under the promissory note. Put another way we have the question whether Section 19 of the Conditional Sales Act would be a bar to the finance company suing and securing a judgment on a promissory note. As we all know the promissory note is generally attached to the bottom of the conditional sale contract by way of a perforation and after completion and signing of the document the promissory note and the conditional sale contract are generally separated. We might wonder whether the two documents might be interpreted as being one. This point is discussed further later in this article and referred to in Aetna v. Breau. ${ }^{11}$

Suffice to say at this point that the attachment of the promissory note by way of a perforation does not as a rule affect any of the rights of a holder in due course. To date we are unaware of any reported case directly on the effect of this Section 19 upon the question whether a vendor after seizing under a conditional sale contract is precluded from claiming a deficiency under the promissory note. However, in the case of Traders Finance Corporation Limited v. Casselman i: the Queen's Bench Division in Manitoba considered such facts in the light of section 19 in the Saskatchewan Limitation of Civil Rights Act, referred to above, and came to the conclusion that insofar as this provincial legislation purported to affect the rights of parties to a promissory note such section was ultra vires and of no effect. We might mention at this point that our own District Court in the case of Modern Motors v. $K_{a u c h e{ }^{73}}$ considered a similar problem; however, with respect to the learned Judge, we are unable to agree with the decision reached in the Modern Motors case. In the Casselman case the trail court gave the finance company judgment on its promissory note notwithstanding the fact that the Limitation of Civil Rights Act purported to restrict the Finance Company's remedy to sale of the unit. This Court relied a great deal upon the reasoning contained in our own Alberta case of Atlas Lumber v. Winstanley. ${ }^{74}$ In the Winstanley case the Court considered whether the Alberta legislature could force the payee of a promissory note to secure governmental permission to take proceedings on its note. Our Court found (and it was supported throughout the higher courts) that the Alberta legislature had no jurisdiction to pass any legislation affecting

\footnotetext{
:110 D.L.R. (2d) 100.

72 (1957) 22 W.W.R. 625.

73(1956) 19 W.W.R. 448.

${ }^{74}[1940] 1$ W.W.R. 35 (Supreme Court of Alberta, [1940] 2 W.W.R. 437 (Alberta Court of Appeal) [1941] S.C.R. 87 (Supreme Court of Canada).
} 
bills of exchange which are the exclusive field of Parliament. ${ }^{75}$ At the time of writing this it appears as if there may be several decisions in the near future directly on the point discussed in this paragraph. For the benefit of the reader we might draw attention to the provisions of the Judicature $\mathrm{Act}^{\text {io }}$ which under Section 31 provides that notice must be given to the Attorney General where it is intended to attack the validity of any act of the legislature.

There is an excellent discussion of this point in the case of Aetna v. Breau ${ }^{71}$ and it would appear from this case that the promissory note and the agreement must be separate and distinct documents in that the promissory note must not refer to the conditional sale contract but the fact that they are attached or on the same piece of paper does not appear to make any difference if each document will stand on its own feet. In the Aetna case the purchaser of a television set had given a promissory note to the conditional vendor as well as executing a conditional sale contract and the vendor had endorsed the note to the plaintiff. The conditional sale contract stated that it was collateral to the promissory note and that it was to be assigned to the plaintiff by the conditional vendor. The Court found that the plaintiff finance company was holder in due course of the promissory note. The Court relied upon our own decision in Killoran v. Monticello State Bank ${ }^{77}$ and that of the Saskatchewan Court of Appeal in Bank of Nova Scotia v. Philpott. ${ }^{\text {:8 }}$

Whether there has been a seizure is in each case a question of fact and perhaps the best discussion as to the manner in which the courts in Alberta are handling this point is to be found in Pacific Finance v. Ireland, ${ }^{70}$ Much depends upon presenting evidence that there has been no force or duress and if possible that the purchaser either returned it voluntarily or concurred in its return. The most common form employed by finance companies appears to be an "Authorization and Consent to Sale Form". Most of these forms simply constitute acknowledgment of the debt, a transfer of the property to the vendor with a direction to sell, pay all repairs, expenses and commission and to credit net proceeds on the indebtedness. It is submitted that this form in itself does not preclude the conditional vendor, or his assignee, from claiming the deficiency in that it is not a seizure in the sense that there is any force or duress used, nor does it in any way alter the purchaser's covenant to pay the purchase price. Sometimes this form is misunderstood by the conditional purchasers in that it is claimed that the authorization and consent to sale form was a release of the purchaser's liability; however, it is in practice extremely difficult to present evidence to this effect since such evidence generally tends

isWe note that the Manitoba Court of Appeal has by a majority reversed the trial decision in the Traders Finance v. Casselman case. See (1958) 25 W.W.R. 289. This case is now being appealed to the Supreme Court of Canada. See also Crescent Finance v. Obin (1958) 25 W.W.R. 219 (Sask. C.A.).

TOR.S.A. 1955 c. 134.

77(1921) 57 D.L.R. 359 (Alberta Court of Appeal).

79[1930] 4 D.L.R. 148 (Sask. Court of Appeal). There is also another case in the Ontario Court of Appeal being Union Acceptance Corporation v. St. Amour 8 D.L.R. (2d) 2.

30[1931] 2 W.W.R. 593. Two other cases on point are Flemings Music House v. Wilkinson [1937] 1 D.L.R. 247 and Fogarty v. Heintzman [1938] 2 D.L.R. 89. 
to contradict, alter or vary the written document and accordingly is inadmissible under the parol evidence rule.

The procedure for effecting a seizure is laid down in the Seizures Act, ${ }^{23}$ but the following may assist as a brief summary of the procedure to be followed. The conditional vendor, generally by his solicitor, completes the usual form of warrant with the conditional sale contract attached, the Form A notice of seizure, the Form B notice of objection and the stamped envelope addressed to the Sheriff. In passing it is important to note the technicality of the documents, particularly the notice of objection, since if all the particulars required in Section $26(1)$ are not included in the documents the creditor might well find himself delayed by technical objections which would invalidate his seizure. After a seizure has been effected the debtor has fourteen days thereafter to file a Notice of Objection to the seizure. In respect of filing a Notice of Objection it is important to note that Section 27 (1) states that it shall be filed "within 14 days" so that if the period of 14 days passed without the filing of the Notice of Objection it would appear that the time has expired and an objection cannot be made afterwards. However, should the period for filing the Notice of Objection lapse, the reader's attention is directed to the provision of Section 34 (1) which would appear to give the debtor a further chance to have the seizure adjudicated upon. If there is no Notice of Objection filed and no proceedings under Section 34(1) the creditor then directs the Sheriff to sell the goods under seizure or if he (the creditor) is entitled, under the terms of the contract, he may get the Sheriff's permission to sell privately in which case he must give the debtor five days notice of his intention to sell and after effecting a sale he must then file with the Sheriff the Statutory Declaration required under Section 30(2) of the Act.

If there is a Notice of Objection filed the creditor must then secure a court order for the removal and sale of the goods under seizure. This application for an order for removal and sale is commenced in the District Court in the district in which the goods were placed under seizure ${ }^{80}$ unless the debtor after seizure consents to the hearing being held in some other district. This application is heard by the District Court regardless of the amount involved. The application is commenced by Notice of Motion which must be served upon the debtor giving him at least seven clear days notice. ${ }^{\text {"t }}$ The Act permits service by registered mail ${ }^{\alpha 2}$ and contains rather elaborate provisions for deeming service good and effective; however, in practice the courts require proof of receipt of the Notice of Motion and one is accordingly advised to effect service only in the usual way of serving court documents. The application is supported by an affidavit which generally requires proof of the contract (true copy as an exhibit), proof of default and the nature thereof, proof of payments made, proof of seizure and proof of the Notice of Objection. The order for sale should provide for the removal and the sale of the unit by public auction or private sale with provisions for cost of seizure, sale and order and all expenses incidental thereto. 


\section{Searches to Make}

I think that we all probably know what searches can be made, though I would not be so sure that we always make them all.

Firstly, of course, except in the case of what are in the 1955 Revision referred to as "itinerant machines", there is the search of the registration records at the court house in the judicial district in which the chattels are located, and any other judicial district in which you may have reason to believe the chattels have been at any time during the past three years. Also a search should be made in the districts where the owners of the chattels have resided, because the primary place for registration of conditional sale contracts is the judicial district in which the owner has resided. This search is a search of the name of the person from whom your client proposes to buy or to whom your client proposes to lend money. In the case of itinerant machines a similar search is to be made at the Central Registry of the Motor Vehicles Branch of the Department of Highways; though in the case of motor vehicles it is possible to search not only the name of the person with whom you are dealing, but to make a search by serial number, a much more effective search.

In either case, the search is usually limited to the preceding three years because conditional sale agreements and most chattel mortgages are not valid if they have not been registered or renewed in the past three years; indeed, at the Motor Vehicles Branch the records tendered for searching cover only the last three to four years. If your proposed vendor or mortgagee is a limited company, or if you know that the chattels have been owned by a limited company, you should make a search at the Companies Branch to see whether there are any bonds, debentures or trust deeds registered there, since these may include either specific mortgages or floating charges which do not nave to be registered as chattel mortgages. The cautious searcher will usually examine both the register of encumbrances (because this is the official record) and the file relating to the company in question (because the document will be filed in it and this affords a cross-check; and because the company may have changed its name so that you will have searched the wrong name in the encumbrances).

Securities taken by a bank under Section 88 of the Bank Act ${ }^{83}$ do not have to be registered as chattel mortgages, but certainly affect the title to chattels. The existence of such security can be discovered by a search at the provincial office of the Bank of Canada in Calgary. While the section is quite long and complicated, it should be read by everyone. I should say at this point that if you are dealing with farmers or fishermen, with manufacturers in respect of goods manufactured by them, or dealers in primary products, you should take this precaution.

Consideration should also be given to the question as to whether or not the property being purchased or on which security is being taken is subject to the rights of a local authority for the collection of taxes, and if there is any

8sR.S.C. 1952 c. 12. 
possibility that this is so, steps should be taken to see that there are no taxes, payment of which could be enforced against the chattels. It may also be advisable to search in the Sheriff's office. While a writ of execution will not prevail against a purchaser in good faith and for valuable consideration, without notice, the situation may be different where there has been a valid and continuing seizure.

Hyndman J.A. in Young v. Dencher ${ }^{84}$ appears to indicate that leaving with the debtor as bailee does not continue the Sheriff's possession. Clarke J.A. said that under the circumstances it did not but that he would hesitate to hold that leaving them for a reasonable time would constitute an abandonment. If it is apparent that there is a seizure, the purchaser will take subject to the rights of the execution creditor.

In the case of licensed motor vehicles, it is possible to have the records of the Licensing Branch of the Department of Highways searched. The fact that a license has been issued for the vehicle in the name of your proposed vendor or mortgagor may not actually prove that he is the owner, but it is a useful precaution to take.

Liens under the Workmen's Compensation $\mathrm{Act}^{22}$ are a charge against chattels, and their existence can be discovered by enquiry from the Workmen's Compensation Board.

I think that it is fair to say that when you have made these searches, necessary though they be, and have found nothing, you have proved exactly nothing. I think also that every solicitor should make this clear to his client, not only so that the client will know what he is getting into, but so that the solicitor may avoid getting into something he does not want, a negligence action.

The first difficulty is this: if you find nothing registered against your proposed mortgagor or vendor, or against the chattel, you have not found anything to prove that he is the owner. If I obtain possession of Mr. Foote's car without his knowledge, and approach your client and offer to sell it to him, I am sure that a search would disclose that there are no encumbrances against the car, but that does not mean that a bill of sale or chattel mortgage executed by me will be of any value to your client. Your search here is not like a search at the Land Titles Office where there is positive evidence as to title.

The next difficulty is this: that there may be an encumbrance registered against the name of some previous owner which you will not discover because you do not know that he was the owner at any time, and therefore do not search his name. For example, if $I$, being the purchaser of a washing machine under conditional sale agreement, sold it to Mr. Foote, then when Mr. Foote in turn sells it to your client, you will search his name and will not find the conditional sale agreement because it is. registered against my name. It is true that this difficulty is avoided in the case of motor vehicles because there is a set of records kept under serial numbers and it is the search by serial number rather than the name which is the primary search so that it does not matter

84[1923] I W.W.R. 136. See now the Seizures Act, supra footnote 23. 
whether I or Mr. Foote was the owner when the encumbrance was given. Presumably you might avoid the difficulty by tracing the history of the chattel and making whatever searches and enquiries are indicated by what you find out, but I am not aware that this is done in practice, and there is always the chance that your information is incomplete or incorrect.

The next, and very similar difficulty, which is also avoided in the case of motor vehicles, is that the person with whom you are dealing may not give you his correct name, so that when you search the name he gives you, you will not find encumbrances registered against him (except in the case of motor vehicles).

The next difficulty is that, although there may be nothing registered at the time of your searches, a document may be registered later and still be entitled to priority over you. A conditional sale agreement will defeat your bill of sale or chattel mortgage if registered within the time allowed for registration and after you have taken your bill of sale or chattel mortgage; and a trust deed, bond or debenture need not be registered at the Companies Branch for 60 to 90 days, and will still be valid. It may be possible to defeat these instruments by withholding payment of your money until the appropriate period has elapsed, though I do not know how often this is done. This precaution would not be effective against chattel mortgages or conditional sale agreements executed before the chattels are removed into the province, or, except in the case of itinerant machines, into another registration district. As has been pointed out, the time for registration runs from notice of removal, and I know of no way of determining when a mortgagee or conditional vendor of whose existence you are ignorant has received such notice. It is possible that even a period of years might elapse before such notice is received.

The next difficulty arises from the provisions in the Conditional Sales Act which I referred to earlier, which enable a conditional vendor to attach his name to the chattel instead of registering his instrument. Presumably this difficulty may be overcome by a close inspection of the chattel, and by enquiring from any person whose name appears on it.

The next difficulty arises from a "sleeper" provision in the Bills of Sale Act. I think that most of you will be surprised to learn that the Crown in the right of the Dominion, the Province, and any Minister is not required to renew any chattel mortgage. This means that your search may not disclose a perfectly valid mortgage, for example, to the Treasury Branch. There may be some doubt as to whether Provincial legislation can require the registration of documents in favour of the Crown in right of Canada. In particular, it has been held that chattel mortgages to the Soldiers Settlement Board need not be registered. ${ }^{85}$

There are a host of other difficulties, and I would not pretend to be able to think of them all. One example would be the difficulties arising from one chattel being more or less attached to another; for example, I was recently asked to search a truck with a portable drilling rig attached; I happened to look

${ }^{85}$ R. v. Powers [1923] Ex. C.R. 131. 
at other documents registered against the proposed vendor's name which according to the records did not refer to the truck in question and found a mortgage of another truck with a rig of similar description attached to it. Another example might be the tires or the tank on a truck. The doctrine of accession may or may not help you. Take oil well drilling equipment such a chattel might today be used for something other than oil so that you would be led to search at the court house instead of at the Central Registry. Then there is always the possibility, though I do not suggest that it is a probability, that the office in which a document is registered has made a mistake, or that a rogue has removed traces of it from the records given to the public for searching. I think at this point I should mention the possibility that a registered document may not reach the public documents immediately on registration; for example, I believe that because of the great number of documents dealt with by the Motor Vehicles Branch, often amounting to 400 a day, particulars do not reach the public records for at least a day so that your search is a day behind. In the case of tractors used for industrial or construction purposes, a further difficulty may arise. These tractors are included in the definition of motor vehicles under the Garagemen's Lien $\mathrm{Act}^{80} s .2$ (b) but are not included in the definition of motor vehicles under the Bills of Sale Act s.2(i). Therefore, while you would normally search at the court house in connection with such a tractor, you might very well find that there is registered at the Motor Vehicles Branch a garageman's lien which will have priority over your instrument.

It may very well be that our practice in Alberta is too careless, probably because we unconsciously assume that title to chattels is in much the same position as the title to land, and that having searched, we have actually accomplished something. At the meeting of the Canadian Bar Association at Banff last September, a Manitoba lawyer, T. Mackay Long, a member of a commercial law panel, said that in Manitoba it was not the custom to rely on registration at all, particularly in view of the fact that that Province has no registration system for conditional sale agreements. In his view it is incumbent upon the purchaser and his solicitor to demand that the vendor produce receipts as to the purchase of the chattel, or that he trace the history of the chattel to the manufacturer. Then it is a matter of making enquiry from the various owners concerned. If the vendor is reluctant to provide the necessary information, or if it appears that he has been in possession of the vehicle only for a very short time, the purchaser is put on his guard and can refuse to proceed with the transaction or can withhold his money until he is satisfied with his vendor's title. Although we may not share Mr. Long's opinion as to the value of a registration system, which he thinks really assists the rogue, there is much to be said for the proposition that a purchaser of chattels, and anyone advising him, should take more precautions than is currently the practice here.

There is a further question which could be conveniently referred to here: suppose that you are acting for a prospective purchaser or mortgagee of

80R.S.A. 1955 c. 128 s. 2 (b). 
chattels and you find through your searches that there is a chattel mortgage registered, but that it does not comply with the statute or has not been renewed as required by the statute, or that you have or your client has knowledge of a prior chattel mortgage which is not duly registered; can you advise him to distegard it? In other words, is a purchaser or mortgagee with notice of the prior encumbrance protected against it?

The leading case on the point is Canadian Bank of Commerce v. Munro ${ }^{87}$ where the bank's chattel mortgage had not been renewed, and Munro had discovered this fact by his search and took a chance on buying the chattels. Although he paid a fair price, the Supreme Court of Canada held that he was not a purchaser in good faith and therefore took subject to the chattel mortgage. Anglin C.J.C., giving the majority judgment, said:

We find it impossible to accept the view that $n$ purchaser who knows that goods which he is buying belong to a third person and that his vendor has neither title to them nor righe to sell them, but, on the contrary, is bound as between himself and such third person to protect the right and title thereto of the latter, and who also knows that any right or title he may acquire by his purchase must be in defeasance of that of such third party can be said, either legally or morally, to be a purchaser in good faith.

It should be noted that the Court inferred from the fact that Munro went with the vendor to cash his cheque, and that the vendor took the proceeds in cash, that Munro knew the vendor had no intention of paying out the mortgage. It might therefore be possible to show good faith, for example by showing that the vendor said the improperly registered document had been paid out, or that he would pay it out.

This case was decided on the old Bills of Sale Act which protected purchasers in good faith. As the Bills of Sale Act stands, the purchasers and mortgagees protected are those claiming from or under the grantor in good faith for valuable consideration and without notice, whose conveyances or mortgages have been duly registered or are valid without registration. The addition of the words "for valuable consideration and without notice" seems to me to put the matter beyond doubt that any purchaser or mortgagee who takes with notice of a prior claim under a bill of sale or chattel mortgage takes subject to that claim. I will not go on to consider what amounts to notice.

The Conditional Sales Act protects purchasers or mortgagees of or from the buyer or bailee of such goods in good faith for valuable consideration. There is no specific requirement that the purchaser or mortgagee must not have notice, and it therefore appears that Canadian Bank of Commerce v. Munro applies, though whether it would be applied in all cases coming within the terms of the statement of Chief Justice Anglin which I have quoted, I do not know.

I think that, whether it is a conditional sale agreement or a prior chattel mortgage of which you have notice, you would be well advised to advise your client not to proceed further until satisfied that the claim is paid off and discharged or that proper allowance has been made for it. While your client might be able to show in the case of a conditional sale agreement

8:[1925] S.C.R. 302. 
that he acted in good faith, as, for example, in the belief that the prior claim had been paid off, or in case of either type of document that what information he had did not amount to notice, it appears to me to be best to tell him that if he proceeds with his sale or mortgage he may be buying a lawsuit.

I should also point out that there have been cases where, when the existence of the prior claim was known to both vendor and purchaser, and discussed by them, and even referred to in the subsequent bill of sale, the courts have held that what the parties were dealing with was only the vendor's interest and that the purchaser took subject to the prior claim, proceeding on the basis that they would not impute to the parties the intention of defeating the prior claim. ${ }^{8 \times}$

\section{Priorities}

Much of this topic has already been covered indirectly. There are, however, several points that might be added.

Comparing the position of the conditional sale contract and the chattel mortgage we find that there is a rather peculiar position in that a conditional vendor has protection for the period allowed for registration whether it be for 21 days for itinerant machines or 30 days in the case of other chattels, while by Section 3(2) of the Bills of Sale Act, a mortgagee has protection only from the date of registration as against the protected classes. It follows that a conditional purchaser could sell the chattel which is the subject matter of the conditional sale contract within the time allowed for registration and a conditional vendor would still have priority over the party who had purchased from the conditional purchaser even though a search would not have disclosed the conditional sale contract.

Respecting priorities qua a landlord we have already mentioned that a conditional vendor has priority over a landlord's claim whether or not the conditional sale contract is registered while on the other hand a landlord has priority over a mortgagee.

The question of priority between a conditional vendor and the holder of a garagemen's lien was considered in the case of In Re Garagemen's Lien Act (In re Gollan and Edmonton Credit Company). ${ }^{*}$ This case was referred to the District Court for a decision under the Rules of Court with respect to four questions, only the third of which interests us here, namely: "Does the lien take priority over the conditional sale agreement held by Edmonton Credit Company Limited?" The case was considered on the basis of the Garagemen's Lien Act, the relevant section, however, being identical to the present one. The Court found that:

Sec. 3 of the statute gives the garageman a "lien on such motor vehicle." There is no limitation in this language. The lien is not limited to a lien on the interest in the motor vehicle of the person incurring the debt to the garageman. Had the garageman secured and retained possession of the motor vehiele he would under The Possessory Liens $A \mathrm{cl}$, . . .

${ }^{88}$ See Lanston Monotype Machine Co. v. Northern Publishing Co. [1922] 2 W.W.R. 529; Banque d'Hochelaga v. Brownstone [1925] 2 W.W.R. 348.

80[1938] 1 W.W.R. 670. 
have acquired prioricy over the respondent (Edmonton Credit) with respect to claims for storage, repaits, etc. . . . The respondent's counsel admits this is the law as applicable to the Co. [1928] 2 W.W.R. 74; Gureritch consideration: Sterling Securities Corpn. v. Hicks Motor Co. v. Siekawiteh [1931] 3 W.W.R 521. Melchoir (1921) 29 B.C.R. 394; J. H. Early Motor 1 K.B. 307. Sec. 10 of The Gor.R. 521; Albemarle Supply Co. v. Hind and Co. [1928] rights... as if he then (after amount of the lien which he has pursuent a Possessory Lien for the same amount as the "rights" include priority over the holder of this condition ..." And, as pointed out, these the language of sec. 5 can be construed to assiat the respondent." agreement. I do not think

The view in the Gollan case was affirmed in Calmar's Garage v. Eric's Late Model Cars Limited ${ }^{\circ 0}$ wherein the learned Judge quoted and approved the following statement from Barron on Automobiles. ${ }^{01}$ The conditional vendee or anyone placed in charge of the car may order repairs to be done
and the implied authority moving from the vendor to such vendee to have repairs made
and in so doing to subject it to a lien, is in way the vendee's part to keep the car free from way cut down or limited by a stipulation on paramount to the claim of the vendor.

These casee cited above deal with priority between a conditional sale contract and garagemen's or possessory liens and it is submitted that the same priority exists as between garagemen's liens and chattel mortgages except in the case where a chattel mortgage was given and registered after the garageman had parted with possession and before he registered his garageman's lien.

In concluding this section on prioritics it might be well to note an older British Columbia case, Alliance Finance Company v. Standard Motors Limit$e d^{j 3}$ which had held otherwise, namely that a provision in a conditional sale contract to the effect that the purchaser will keep the unit free from all liens and encumbrances disentitled a garageman to priority under a garagemen's lien; however, our Alberta Courts do not follow this decision but prefer to rely on Commercial Credit v. Stratford..$^{93}$ It would appear that the British Columbia Courts have now also discarded the Alliance Finance view as witness General Securities Ltd. v. Bretts Ltd. ${ }^{04}$ a decision of the Supreme Court of British Columbia giving an excellent discussion of the topic.

Me. Hurlburt presented ss. 1, 3 (c) and 6; Mr. Foote ss. 3 (a-d), and 4; and Mr. Hope ss, 2, 5, and 7.

${ }^{00}$ (1956) 19 W.W.R. (N.S.) 382

01 John A. Barron, The Law of Automobiles and Motor Vehicles in Canada, 1926, p. 164.
92[1928] 3 W.W.R. 621.

09(1920) 47 O.L.R. 392.

01(1956) 19 W.W.R. (N.S.) 385. 
